\title{
The Humanitarian-Development-Peace Nexus: Solving Rubik's Cube in Policy and Practice
}

\author{
Diego A. Cimino \\ Directorate General for Development Cooperation, \\ Ministry of Foreign Affairs and International Cooperation, \\ Rome, Italy
}

\begin{abstract}
Historically, the 20's of each of the last centuries proved to be challenging years, where moments of historical opportunities were followed by daunting global difficulties. The 20's of this $21^{\text {st }}$ Century clearly followed the same historical destiny, with still an uncertain ending. Even before the Covid-19 pandemic, the geopolitical, economic, social and environmental complexities of today's world appeared as inter-connected as ever before. The aim of this paper is to analyze most discussed nexuses in the international policy-making space, the so called "HumanitarianDevelopment-Peace Nexus" or "Triple-Nexus", referred to the gradual coordination, cooperation, integration and interaction of humanitarian, development and peace actions and actors at all levels.
\end{abstract}

Keywords: peace, sustainable development, humanitarian action, globalization, "Triple-Nexus", 2030 Agenda

Peace and development are essential needs, reachable aspirations, complex and interconnected processes, as they complement and serve each other along the way.

\section{Context, Trends and Definition}

Over the last two decades, as effect of globalization, the concept of inter-dependence has emerged stronger while, in parallel, the pre-existing international political and economic structures appeared not to be able to adapt consequently to such existing reality. As a consequence of these complexities, despite unprecedented, recorded progresses in development, wealth and opportunities over the last two decades, structural challenges to peace and sustainable development persisted, particularly in the most fragile areas of the world where crisis, violence and fragility remained and, in some cases, actually increased, hitting particularly the most vulnerable and in need.

In such a context, inter-connections and nexuses can not only better explain today's world dynamics than monothematic approaches or "lenses", but they can also offer new transformative approaches to assess and address those structural challenges, in order to find innovative solutions and achieving peace and sustainable development as part of 


\section{Journal of International Cooperation and Development \\ www.richtmann.org/journal \\ Vol 3, No 1, May 2020}

one comprehensive, multi-dimensional - yet still very complex - plan of action. As a consequence of this increased awareness, inter-connections and nexuses entered both the policy-making and the operational spaces, while the international community is currently attempting to face the challenges of their effective, integrated implementation, as if being in front of a global "Rubik's Cube", where all the issues are put together and one action at the same time is instrumental and affects the whole cube.

Arguably, among the most discussed nexuses in the international policy-making space there is the so called "Humanitarian-Development-Peace Nexus" or "TripleNexus", referred to the gradual coordination, cooperation, integration and interaction of humanitarian, development and peace actions and actors at all levels. This nexus, sometimes defined also as a 'continuum' between the three areas, calls for all actors to strengthen their collaboration in a coordinated, coherent and enhanced manner, towards effective and efficient integration or complementarity processes. This includes more coordination and possible joint-programming and implementation, in order to achieve collective and mutually-reinforcing outcomes fit for the challenging, multidimensional contexts in which actors are called to operate for peace, development and humanitarian action. Multilateral cooperation and relevant multilateral governance fora constituted the ideal platform to agree on key principles and improve policy and operational evolution of this nexus: the cube with three different dimensions to be solved.

Data and evidence prove, if needed, that a less peaceful world is a much more challenging place to fight inequality and achieve sustainable development and, at the same time, it is harder to build or maintain peace in a world filled with inequalities, injustices and lack of sustainable development. According to the Global Peace Index of the Institute of Economics and Peace, since 2008 global peacefulness has deteriorated by $3.76 \%$, with more than the $40 \%$ of Countries in the world recording a deterioration ${ }^{1}$. The same Institute, on its 2018 'The Economic Value of Peace' ${ }^{2}$, reports that in 2017 the economic impact of violence to the global economy was $\$ 14.76$ trillion $^{3}$, equivalent to $12.4 \%$ of global gross domestic product (GDP). According to the same Institute, the same value in 2019 increased to $\$ 14.5$ trillion.

The inter-relation between violence, economic prosperity and social justice is multidirectional: while conflict and violence have negative implications for economy and prosperity, at the same time, high levels of poverty or low levels of social services are conducive to increased instability, which can erupt in conflict. This vicious cycle of social insecurity, poverty and instability, repeats its formula various combinations: Countries

\footnotetext{
${ }^{1}$ http://visionofhumanity.org/indexes/global-peace-index/

${ }^{2}$ http://visionofhumanity.org/app/uploads/2018/11/Economic-Value-of-Peace-2018.pdf

${ }^{3}$ In constant purchasing power parity (PPP)
} 


\section{Journal of International Cooperation and Development}

www.richtmann.org/journal

Vol 3, No 1, May 2020

experiencing different degrees of violence face poverty at significantly higher rates; people in unstable, fragile or conflict-affected countries are more than twice as likely to be under-nourished or facing other forms of vulnerability as those in other developing countries; children in conflict zones are more than three times less likely to attend school, and twice as likely to die before the age of five; nine out of 10 countries with the lowest human development index have experienced conflict within the past 20 years ${ }^{4}$.

Recently, in a joint landmark report ("Pathways for Peace") the UN and the World Bank estimate that by 2030 over half of the world's poor will be living in Countries affected by high level of violence ${ }^{5}$. Additionally, in this new and more challenging Covid19 world, according to the most recent World Bank estimates ${ }^{6}$, between 71 million and 100 million people could fall again in extreme poverty in 2020 only.

From the humanitarian point of view, the UN High Commissioner for Refugees (UNHCR) has recently highlighted that of almost 89 million people ( $1 \%$ of the global population, $40 \%$ of which are children) currently forcibly displaced, 45.7 million are internally displaced, 26 million people refugees, 4.2 million asylum seekers ${ }^{7}$ and that about $85 \%$ of the refugees are hosted in developing Countries. This creates an overwhelming pressure on already fragile, least developed or developing Countries such as Lebanon, Jordan, Chad, Uganda, Sudan, which are currently five of the top six per capita refugee-hosting countries. Furthermore, it has to be noted that $68 \%$ of the total refugee population in the world comes just from 5 Countries, most of them conflictaffected: Syria, Venezuela, Afghanistan, South Sudan and Myanmar. In the context of multiple protracted crises, with refugee camps and other settlements standing for decades, the scale of needs moved beyond the traditional phases of humanitarian aid (relief, recovery and rehabilitation) and called for more structural and mid-long term interventions also in humanitarian settings, particularly in the fields of health, education, social services, economic measures, skills development. From this point of views, a new declination of "resilience", defined as the capacity to strive beyond challenges, and as bridge between humanitarian and development processes and of development in humanitarian or emergency contexts, has emerged in policy and practice.

Resilience-building became a new humanitarian, development, peace-building priority. In areas like the Sahel region in Sub-Saharan Africa, these concepts find clear representations, where endemic poverty is often linked with or caused by humanitarian crises, food insecurity and fragility caused by climate change - like in the case of the Lake Chad Basin - or by conflicts. Intervening with poverty alleviation measures, food aid or

\footnotetext{
${ }^{4}$ UNDP Data: https://www.undp.org/content/undp/en/home/blog/2014/7/11/how-can-wepromote-peace-and-development-at-the-same-time.html ${ }^{5}$ https://www.worldbank.org/en/topic/fragilityconflictviolence/publication/pathways-for-peaceinclusive-approaches-to-preventing-violent-conflict ${ }^{6}$ https://blogs.worldbank.org/opendata/updated-estimates-impact-covid-19-global-poverty ${ }^{7}$ https://www.unhcr.org/ph/figures-at-a-glance
} 


\section{Journal of International Cooperation and Development \\ www.richtmann.org/journal \\ Vol 3, No 1, May 2020}

agricultural development from one side, or ensuring key human development services such as health services, education, skills development, means at the same time reducing humanitarian needs, planting seeds of development and limiting further causes of violence or conflict, therefore building peace.

These data clearly show the reason for implementing effective, joint measures to deliver on the humanitarian-development-peace nexus. The nexus approach aims at strengthening coherence, coordination and complementarity among the three areas both in policy and practice, with a view to establishing more joint actions, programming and actual integration in the field, where the complex realities are still more inter-linked than at policy-level.

At global level, the 2030 Agenda for Sustainable Development, adopted by the 193 Member States of the United Nations in 2015 at the UN Sustainable Development Summit, responds to the new challenges of inter-connection and constitutes nowadays the new global framework for integrated policies for peace, planet, prosperity and people. The 2030 Agenda sets a vision for our common future and establishes a measurable set of objectives and targets (17 Sustainable Development Goals, SDGs and 169 related targets) which not only integrate the human, economic, social and environmental dimensions of development in the new 'Sustainable Development' paradigm, but clearly affirms that "there can be no sustainable development without peace and no peace without sustainable development" ${ }^{8}$. From this perspective, we can arguably define the 2030 Agenda as the most comprehensive policy-framework integrating the three pillars, set by the United Nations Charter: peace, human rights and development.

Operationalizing the nexus between humanitarian, development and peace will be instrumental for achieving these ambitious goals. It constitutes one of the key challenges for the international system, including in particular the United Nations Development System, the International Financial Institutions (IFIs), regional organizations, bilateral and multilateral aid actors and, of course, governments, societies and their communities. It is not demanded to just one specific authority or agency to deliver on the nexus, it is rather a system-wide approach in which each actor involved, from the political to the military, from the development to the humanitarian, from the social to the economic ones, have the responsibility to fulfill their own 'piece' in a more integrated manner than in the past.

The reformed and reinvigorated UN Development System will play a crucial role to ensure that the operational activities for development and for humanitarian action give their essential, collective contribution to peace, in particular through economic development, poverty eradication and social inclusion. According to the new system, when the context requires it, the UN Resident Coordination maintains the role of

\footnotetext{
${ }^{8}$ Preamble of the 2030 Agenda for Sustainable Development (A/RES/70/1)
} 


\section{Journal of International Cooperation and Development \\ www.richtmann.org/journal \\ Vol 3, No 1, May 2020}

Humanitarian Coordinator, in order to better align processes and activities and implement the nexus.

According to the latest available data, the United Nations System dedicates $76 \%$ of its total operational country-level expenditure in the so called 'crisis-affected Countries'. Figures reported in the latest Report of the Secretary General ${ }^{9}$ on the activities for sustainable development show the UN operational and peace related expenditure in crisis-affected countries, differentiating the mix of different 'set' of resources invested, namely humanitarian, development, peace-keeping and political affairs. Overall, for the same group of 50 crisis-affected countries, $24 \%$ of total resources are developmentrelated, $27 \%$ peace and security-related and $49 \%$ devoted to humanitarian activities. Only by looking at the UN system through this 'blend' it is possible, at least quantitatively, to detect the triple nexus. It has then to be seen, qualitatively, how the streams communicate and complement each other on the ground. According to those data, the top eleven Countries per expenditure are, in order: South Sudan, Democratic Republic of the Congo, Lebanon, Somalia, Sudan, Mali, Yemen, Afghanistan, Central African Republic, Syria, Iraq. Interestingly, the blend of resources change based on the Country context.

Looking beyond the UN System, it is worth mentioning that the World Bank Group's International Development Association (IDA), the branch of the World Bank in charge of least developed Countries, has doubled in 2018 its financing for low-income countries impacted by fragility, conflict and violence, from 7 billion to 14 billion US \$, including for long term investments in sustainable development of those Countries such us in the sectors of job creation and private sector development in fragile contexts. Furthermore, the World Bank in partnership with the UN have established the "HumanitarianDevelopment-Peace Initiative"10, a new partnership-based instrument which identifies collective outcomes and deliver comprehensive and integrated responses to Countries at risk, in protracted crisis or post crisis. This initiative, started in 2017 through the UNWorld Bank Fragility and Conflict Partnership Trust Fund, was operationalized in Cameroon, Somalia, Yemen and Sudan, complements the structural work of the World Bank in its "Fragility, Conflict and Violence Group".

With just a decade until 2030, the challenges to overcome were enormous even before the Covid-19 and required acceleration, ambition and commitment from all the actors involved. For this reason, the United Nations declared the next ten years as the 'Decade of Action' for achieving the Sustainable Development Goals (SDGs).

Now, the global efforts will be focused on defeating the coronavirus, mitigating its

\footnotetext{
${ }^{9} 2019$ Secretary-General's Report on the implementation of the Quadriennal Comprehensive Policy Review (A/74/73 - E/2019/4)

${ }^{10}$ https://www.worldbank.org/en/topic/fragilityconflictviolence/brief/the-humanitarian-developmentpeace-initiative
} 


\section{Journal of International Cooperation and Development \\ www.richtmann.org/journal \\ Vol 3, No 1, May 2020}

multi-dimensional impact in all contexts and beginning the global recovery according to the emerging concept of "recover better" which implies, among other elements, addressing inequalities, building resilience and establishing new and greener human, economic and social development processes and lifestyles for all, in order to maintain the pathway towards the Agenda 2030 horizon. The key element to respond effectively to this unprecedent crisis lies exactly on the challenges of integrated actions and coordination. The COVID-19 crisis represents, from this perspective, a fundamental testing point also to implement the humanitarian-development-peace nexus.

This paper will further present the policy evolution of the relation between Peace and Sustainable Development in the UN context, including through the lenses of the 2030 Agenda for Sustainable Development and the emerging 'Sustaining Peace Agenda', and show concrete examples of its application in the context of sustainable development operations and programs, including a focus on the role of the so-called 'UN Peacebuilding Architecture', the wider UN Development System and other international organizations and the relation with the humanitarian action.

\section{International Policy Evolution - Three Pillars in One Nexus: From the "Agenda for Peace" to the 2030 Agenda, the "Sustaining Peace" and the "New Way of Working"}

Since its foundation, the United Nations system and its Member States have been working to integrate the three mentioned 'UN Pillars', facing the challenges posed by the reality of implementing the high objectives of the UN Charter, from one side, and the difficult development processes faced by developing Countries, from the others. When dealing with peace and development, the inevitable truth discovered in practice by Governments and International actors has been that it is impossible to succeed in one area without investing in the other area. This fate of inter-dependence was firstly, clearly and officially stated - interestingly - by the UN Security Council, on the occasion of a first remarkable Summit on 1 January 1992, where the Council convened for the first time at head of State and Government level, which, in recognizing the limits of UN peace-keeping operations, issued a statement, which, among other elements, reported that:

"The absence of war and military conflicts amongst States does not in itself ensure international peace and security. The non-military sources of instability in the economic, social, humanitarian and ecological fields have become threats to peace and security. The United Nations membership as a whole, working through the appropriate bodies, needs to give the highest priority to the solution of these matters. ${ }^{\prime 11}$

\footnotetext{
${ }^{11}$ Security Council Summit Statement Concerning the Council's Responsibility in the Maintenance of International Peace and Security, 47 UN SCOR (3046 ${ }^{\text {th }}$ meeting) UN Doc. S/23500 (1992), UNYB 33
} 


\section{Journal of International Cooperation and Development \\ www.richtmann.org/journal \\ Vol 3, No 1, May 2020}

This statement laid the foundations of a then-groundbreaking report by the then UN Secretary-General, Boutros-Ghali, the so called 'Agenda for Peace'. The Secretary General's Agenda opened the pathway for comprehensive and synergetic peacebuilding, peace-keeping and preventive diplomacy actions, which moved beyond the solely militaristic approach to the maintenance of international peace and security and called for an integrated approach, which included development in the set of integrated actions for both post-conflict peace-building and preventive diplomacy.

Since then, the international architecture has developed further, with the constitution, in 2005, of a new 'UN Peace-Building Architecture', established jointly by the UN General Assembly and the Security Council ${ }^{12}$, composed by an intergovernmental body, the Peacebuilding Commission (PBC) - with the objective, among others " $(b)$ To promote an integrated, strategic and coherent approach to peacebuilding, noting that security, development and human rights are closely interlinked and mutually reinforcing;"-, the Peacebuilding Support Office (PBSO) and an ad-hoc fund, the Peacebuilding Fund (PBF), aimed at improving a more comprehensive approach to peace-building strategies, policies and programs and accelerating actions and impact for peace and development.

The 'Peacebuilding Fund', represents the financial and operative institution of the Peacebuilding Architecture. From 2015 to 2018, the Fund has allocated over 368 million US $\$$ to 47 recipient countries and, according to the data ${ }^{13}, 83 \%$ of the Peacebuilding Fund investments can be directly linked to one or more SDG's targets (38\% towards targets under SDG 16 on peace, justice and strong institutions; $11 \%$ towards targets under SDG 10 on reducing inequalities; $10 \%$ towards targets under SDG 5 on gender equality; $8 \%$ towards targets under SDG 4 on quality education; $5 \%$ towards targets under SDG 8 on decent employment and livelihoods; $11 \%$ towards targets under other Goals.

More recently, after the adoption of the 2030 Agenda and the 2015-2016 Review of the Peacebuilding Architecture culminated with the adoption of two new 'Twin Resolutions' - adopted respectively by the General Assembly and the Security Council ${ }^{14}$-, a new conceptual shift occurred, an emerging approach, particularly promoted by the UN Secretary-General Antonio Guterres and officially recognized and denominated 'Sustaining Peace'. The Sustaining Peace Agenda could be seen as a high-level agenda on the triple nexus, encompassing also the ongoing Secretary-General's integrated, threepillars reform of the United Nations, namely working to improve and move closer the Peace and Security Pillar, the Development System Pillar and the Operational and

\footnotetext{
${ }^{12}$ Resolutions: UNGA A/RES/60/180 and Security Council S/RES/1645 (2005)

${ }^{13}$ Peacebuilding Fund Investment in the Sustainable Development Goal Report - May 2019 Report https://www.un.org/peacebuilding/sites/www.un.org.peacebuilding/files/documents/1907427-epbf-investments-in-sdgs-web.pdf

${ }^{14}$ Resolution GA/70/262 and Security Council Resolution S/RES/2282 (2016)
} 
Management Pillar of the United Nations. These ongoing reforms aim not only at making the UN system more effective and efficient at all levels, but also at the effective implementation of these 'inter-connections'.

The 'Sustaining Peace' approach, being it both a concept and a living agenda, encompasses all the necessary political, social, economic, cultural activities to be carried out to maintain peace and security along all the potential phases of a peace-building process, from prevention to post-conflict, ensuring coordinated, coherent and consistent efforts by all international, governmental and non-governmental actors involved in quest for peace and development.

In 2016, the General Assembly and Security Council 'Twin' Resolutions on the Review of the UN Peacebuilding Architecture precisely emphasized:

\begin{abstract}
"the importance of a comprehensive approach to sustaining peace, particularly through the prevention of conflict and addressing its root causes, strengthening the rule of law at the international and national levels, and promoting sustained and sustainable economic growth, poverty eradication, social development, sustainable development, national reconciliation and unity, including through inclusive dialogue and mediation, access to justice and transitional justice, accountability, good governance, democracy, accountable institutions, gender equality and respect for, and protection of, human rights and fundamental freedoms ${ }^{\prime 15}$.
\end{abstract}

The 2030 Agenda offers even a broader platform for integration of peace and development activities, not only referring to the two processes as interconnected but directly considering their integrated implementation through at least three specific components. Firstly, 2030 Agenda has 'Peace' as one of its 5 core pillars or 'dimensions' ${ }^{16}$, where this interconnection is restated. Secondly, an ad-hoc Sustainable Development Goal on peace, justice and strong institutions has been universally agreed: "SDG 16 Promote peaceful and inclusive societies for sustainable development, provide access to justice for all and build effective, accountable and inclusive institutions at all levels" with its 10 measurable targets are specifically devoted to those key aspects of governance, rule of law, justice which directly contribute to peaceful and inclusive institutions and societies. It is worth referring the SDG 16 targets below:

SDG 16

16.1 Significantly reduce all forms of violence and related death rates everywhere;

16.2 End abuse, exploitation, trafficking and all forms of violence against and torture of children;

\footnotetext{
${ }^{15}$ Resolution GA/70/262 and Security Council Resolution S/RES/2282 (2016)

${ }^{16}$ The five dimensions, listed in the Preamble of the Agenda (cfr. A/RES/70/1) are People, Planet, Prosperity, Peace and Partnership. Under the 'Peace' reference, the interconnection between peace and development is restated.
} 


\section{Journal of International Cooperation and Development}

www.richtmann.org/journal

Vol 3, No 1, May 2020

16.3 Promote the rule of law at the national and international levels and ensure equal access to justice for all;

16.4 By 2030, significantly reduce illicit financial and arms flows, strengthen the recovery and return of stolen assets; and combat all forms of organized crime;

16.5 Substantially reduce corruption and bribery in all their forms;

16.6 Develop effective, accountable and transparent institutions at all levels;

16.7 Ensure responsive, inclusive, participatory and representative decision-making at all levels;

16.8 Broaden and strengthen the participation of developing countries in the institutions of global governance;

16.9 By 2030, provide legal identity for all, including birth registration;

16.10 Ensure public access to information and protect fundamental freedoms, in accordance with national legislation and international agreements;

16.a Strengthen relevant national institutions, including through international cooperation, for building capacity at all levels, in particular in developing countries, to prevent violence and combat terrorism and crime;

16.b Promote and enforce non-discriminatory laws and policies for sustainable development.

Thirdly, it has been noted that at least 34 targets related to 8 different SDGs ${ }^{17}$ (the so called 'SDG $16+{ }^{\prime 18}$ ), directly contribute to the advancement of peace, justice or inclusion, leading to a mainstreaming of peace/justice-contributing actions in the 2030 Agenda.

It is possible to state that the 2030 Agenda adheres to the renowned concept of 'Positive Peace' ${ }^{19}$, where 'Peace' is not intended as the absence of a violent conflict, but as a more complete concept of social harmony, economic prosperity, good governance, cultural dialogue, non-discriminatory enjoyment of fundamental freedoms and human rights by all. From this perspective, the 2030 Agenda for Sustainable Development and its SDGs, including but not just limited to SDG 16, can serve as a real 'infrastructure' for peace, where SDG 16 can be regarded as a 'Nexus Enabler', the backbone for strengthening resilient public services for peace and development.

From this perspective, the 2030 Agenda arguably represents the best mix of measures to prevent violence and conflict by tackling their root causes, including food security, lack of access to basic needs, rights and services such as health or education

\footnotetext{
${ }^{17}$ Targets included in SDG 1 on Poverty, SDG 4 on Education, SDG 5 on Gender Empowerment, SDG 8 on Decent Work, SDG 10 on Inequalities, SDG 11 on Sustainable cities, SDG 16 on Peace, Justice and Strong institutions, SDG 17 on Partnerships)

${ }^{18}$ https://www.sdg16.plus/roadmap

${ }^{19}$ Inspired by philosophers, including St. Augustine and Immanuel Kant, it has developed as a sociological concept by Johan Galtung and then elaborated by several authors and organizations, including for the elaboration of the 'Global Peace Index'
} 


\section{Journal of International Cooperation and Development \\ www.richtmann.org/journal \\ Vol 3, No 1, May 2020}

injustice, social exclusion, limitation or violation of human rights, inequalities, corruption. From this perspective, it could be then seen as an effective preventive agenda: the more a society is equal, just, inclusive, the more it is rooted in peace and prosperity. At the same time, the more fragile the social texture is in a given community or countries, the higher is the risk of violence and conflict. Inclusive sustainable development, where no one is left behind, represents the best defense against the risks of violent conflict.

Such approach built on previous global frameworks such as the outcomes of the "World Humanitarian Summit" (Istanbul, 2016), which also adopted the so called "Grand Bargain", a multi-stakeholders agreement between 61 signatories (24 Governments, 11 UN Agencies, 5 inter-governmental organizations, the Red Cross/Red Crescent Movement and 21 major non-governmental organizations), which represent about the $73 \%$ of all humanitarian contributions globally. Signatories agreed to improve effectiveness and efficiency of the humanitarian action, working across nine "workstreams": greater transparency; more support and funding tools to local and national responders; increase the use and coordination of cash/based programming; reduce duplications and management costs; improve joint and impartial needs assessment; increase multi-stakeholders participation in decision-making; increase humanitarian multi-year planning and funding and quality funding; harmonize and simplify reporting and, as a mainstreamed thematic, enhance engagement between humanitarian and development actors.

As part of the new UN Development System Reform, in 2018 a Joint Steering Committee on Humanitarian and Development Collaboration was constituted, chaired by the Deputy Secretary-General of the United Nations and composed by all the UN entities, agencies, funds and programs operating in fragility contexts, aimed at sustaining the nexus and the UN Country Teams in charge of its implementation at Country-level. These operations include more coordination in planning, including jointanalysis and planning, enhanced cooperation, complementarity and coherence, respecting needs-based assessment and contextualized, tailored approaches.

The UN Agencies, Fund and Programs, are at the frontlines of the nexus implementation, especially those working within both humanitarian and development mandates or with the aim of bridging humanitarian and development priorities, such us the World Food Program, UNICEF, UNFPA, UNHCR, UNDP, UN Women, in partnership with key UN Departments like the UN Department for Political and Peace-Building Affairs and the UN Department for Peace-Keeping Operations and their respective Countries' and Fields' missions.

Implementing the humanitarian-peace-development nexus in Country-contexts requires, however, greater efforts of coordination among the relevant actors. From the 


\section{Journal of International Cooperation and Development \\ www.richtmann.org/journal \\ Vol 3, No 1, May 2020}

operational side, a 'New Way of Working (NWow)'20 has emerged within the United Nations System as a set of operational principles which "calls on humanitarian and development actors to work collaboratively together, based on their comparative advantages, towards 'collective outcomes' that reduce need, risk and vulnerability over multiple years" for which implementation and further elaboration a Joint Steering Committee to advance humanitarian and development cooperation has been established.

The way ahead towards the implementation of the peace-development nexus, and the triple nexus, will require:

1) Structural efforts towards a global and inter-sectoral policy-coherence;

2) Strategic, financial and operational coordination among actors, both multilateral and bilateral, governmental and non-governmental, starting from the cooperation between military, political and development entities on the ground;

3) Commitment from national and local governments to own the Sustaining Peace Agenda at Country-level.

\section{A Focus on Italy: Advocate, Donor and Convener for Peace and Sustainable Development for All}

In this context, Italy is engaged to advance the humanitarian-peace-development nexus and the triple nexus, both in its bilateral action and as an actor and contributor to the wider multilateral system. As recently acknowledged by the Organization for Economic Cooperation and Development (OECD)'s Peer Review of the Italian Development Cooperation (2019), "Italy has a long tradition of engaging in fragile and crisis countries, and all of Italy's priority countries and countries of operation are among the top 40 fragile countries and territories in the OECD fragility framework. A strong field presence, including by its own non-government organizations (NGOs) in fragile and conflictaffected states, helps Italy contextualize and adapt its co-operation“. ${ }^{21}$

The Italian action on the nexus finds its area of engagement in the Mediterranean Region and in the most fragile areas of Sub-Saharan Africa, such as the Horn of Africa and the Sahel. In these areas, Italy works on multi-dimensional approaches to conflict and violence prevention, including working on long-term development needs in protracted humanitarian crisis -settings such as refugees and displaced camps, rural areas, working on basic services from health to education to developing entrepreneurial skills or working on capacity-building in the sector of cultural heritage and agriculture.

\footnotetext{
${ }^{20}$ https://www.un.org/jsc/content/new-way-working

${ }^{21}$ OECD DAC Peer Review of the Italian Development Cooperation, 2019: https://www.oecdilibrary.org/sites/b1874a7a-en/index.htm/?itemld=/content/publication/b1874a7a-en\&mimeType $=$ text $/ \mathrm{htm} /$ \&_csp_=d142970d2ab4e64232e4558df07d8090\&itemIGO=oecd\&itemContentType=book
} 
Just to mention a few concrete examples, between 2017-2019, Italy has been contributing to targeted initiatives in Syria, Lebanon, Libya, Iraq, Afghanistan, Somalia, Palestine, Ethiopia and Sudan to work in the areas of resilience of communities and institutions, access to services and opportunities for displaced and refugees, quality education in conflict-affected areas, institutional capacity-development, poverty alleviation, local agro-business development, promoting women and youth agency and inclusion at all levels in line with the Women, Peace and Security Agenda and the Youth, Peace and Security Agenda ${ }^{22}$. All of these initiatives directly related to a successful implementation of the peace-development nexus and working for sustainable development in fragile settings.

Italy further supports multilateral efforts to implement the peace-development nexus in post-conflict and conflict affected areas by contributing, among others, to the 'Funding Facility for Immediate Stabilization in Iraq'23, the 'Law and Order Trust Fund' for Afghanistan $^{24}$, the World Bank's 'Afghanistan Reconstruction Trust Fund'25, the Stabilization Facility for Libya ${ }^{26}$, the 'Joint Peace Fund' for Myanmar ${ }^{27}$, the EU Trust Fund for Peace Colombia ${ }^{28}$.

Italy is also one of the major contributors to the UN Development Program (UNDP), focusing especially on tackling root cause of migration and building resilience to prevent and mitigate the impact of crisis and conflicts by helping to stabilize societies, support or rebuild institutions in some of the most challenging development contexts in the world. According to UNDP data ${ }^{29}$, the top recipients of Italian funding through UNDP are indeed Afghanistan, Iraq, Libya, Palestine, Lebanon, Egypt, Tunisia and Sudan. The programs focus, for example, to support Lebanese and Syrians towards improved livelihoods, social services, primary health care, training for agriculture and agrifood cooperatives; repairing 11 hospitals, providing medicines and supplies, and rehabilitating 16 schools and municipal services in Libya.

Italy, therefore, supports the implementation of the nexus, starting from

\footnotetext{
${ }^{22}$ UN Security Council Resolutions 1325 (2000), 2250 (2015), 2282 (2016), 2419 (2018)

${ }^{23}$ Main objectives: Rebuilding schools and hospitals; Rehabilitating water systems and electricity networks; Providing short-term employment through public works schemes; and rehabilitating houses damaged by ISIL. Managed by UNDP.

${ }^{24}$ https://open.undp.org/projects/00089137

${ }^{25}$ http://www.artf.af/

${ }^{26}$ https://www.ly.undp.org/content/libya/en/home/projects/Stabilization-Facility-for-Libya.html

${ }^{27}$ Strengthening conflict management mechanisms created by ceasefire agreements (outcome 1); supporting formal and informal negotiations and dialogues (outcome 2); and promoting inclusivity through broad participation in the peace process (outcome 3). Managed by UNOPS.

${ }^{28}$ https://ec.europa.eu/europeaid/eu-trust-fund-colombia_en

${ }^{29}$ https://www.undp.org/content/dam/undp/library/corporate/PG_Brochures/UNDP_PG_Italy_Br ochure.pdf
} 


\section{Journal of International Cooperation and Development \\ www.richtmann.org/journal \\ Vol 3, No 1, May 2020}

intervening in the so called 'protracted crises', such as in the context of the more than 10-years long Syrian conflict, where increasingly more resilience-building actions are needed in addition to the typical relief measures to sustain civilian affected, or in the contexts of long-standing refugee camps and other displaced settings. These measures and interventions are regarded as key actions, to provide, protect and sustain the most vulnerable and affected people, from one side, and, from the others, also to support hosting communities, which, as argued, are themselves often fragile and developing Countries (such as Jordan, Lebanon, Uganda, three of the highest host Countries of refugees per capita in the world) facing several level of challenges in their development process, including in the context of integration and services providing.

Additionally, Italy has also been among the main supporters of the UN Peacebuilding Fund and it is currently among the top 20 donors at global level. Italy has also earmarked financing specifically to initiatives for women and young people's empowerment, which are considered key agents and actors in development and peacebuilding, and on which role of peace-builders, mediators and protagonists of development processes in the local, national and international contexts, Italy is consistently investing and advocating for, in line with the Women, Peace and Security and the Youth, Peace and Security Agendas, introduced with UN Security Council Resolution 1325 and 2250, which encompass a "triple nexus approach" along humanitarian, development and peace dynamics.

As a proactive multilateral actor in the policy-making fora, Italy has been among the major supporters of SDG16+ targets in the Agenda 2030. This was also linked to the traditional importance attached to the promotion of rule of law and human rights, also as development enablers.

As a further demonstration of this commitment, Italy was chosen by the United Nations to host the first global, preparatory, thematic review of SDG 16, in the context of the monitoring process of the implementation of the 2030 Agenda culminating in the annual UN High Level Political Forum for Sustainable Development (HLPF). The meeting, co-organized with the United Nations Department of Economic and Social Affairs (UNDESA) and the International Development Law Organization (IDLO), hosted in Rome in May2019 at the Italian Ministry of Foreign Affairs and International Cooperation and denominated "Peaceful, Just and Inclusive Societies: SDG 16 implementation and the path towards leaving no one behind", brought together over 300 participants from national governments, United Nations entities, international organizations, the private sector, local governments, academia and civil society, including several youth participants. It served as a global, multi-stakeholder platform to discuss and explore the state of SDG 16 implementation, which took stock and analyzed the challenges and 


\section{Journal of International Cooperation and Development \\ www.richtmann.org/journal \\ Vol 3, No 1, May 2020}

opportunities and the status of implementation of SDG 16 and SDG $16^{30}$, directly reporting to the HLPF. In order to promote the meaningful engagement of young people in policy and decision-making spaces, a key role in the Conference was reserved to 16 young leaders involved in local actions in developing countries for the achievement of the SDG16+ and other civil society delegates championing SDG 16+ at local level, whose positions were fully integrated in the outcomes of the Conference as well as into the 'Rome Civil Society SDG16+ Declaration'31 and in the entirely youth-led 'Rome Youth Call-to-Action on SDG $16^{\prime 32}$.

Italy, which is also one of the members of the OECD's "International Network on Conflict and Fragility (INCAF)", is currently developing its "Strategic Guidelines on the humanitarian-development-peace nexus" in line with the OECD Development Assistance Committee's Recommendation on the Humanitarian-Development-Peace Nexus, with the purposes of:

- alleviating the immediate humanitarian needs while reducing long-term vulnerabilities;

- strengthening programmatic synergy between humanitarian and development programs, including the 'peacebuilding' dimension;

- working on comparative advantages of its programs and coordinating with the wider international and local systems.

Italy has set among its development cooperation priorities to continue to be an engaged actor, convener and committed implementer of the humanitarian-peacedevelopment nexus, as a fundamental directive towards the achievement of the Sustainable Development Goals and the aspiration of more prosperous, peaceful and inclusive world.

\section{Conclusions}

The faith of inter-dependence between peace and sustainable development processes is inevitable. The emerging approaches of 'Sustaining Peace', the 'Humanitarian Development- Peace Nexus' or 'Triple Nexus' and the new ad-hoc approaches on working in fragility and protracted crisis being implemented by multilateral and bilateral actors can have major positive implications for new, ambitious, long-term joint outcomes. Working on 'one dice', to solve this Rubik's cube is the only way to find sustainable, long term, successful solutions for achieving Peace and Sustainable Development for all.

\footnotetext{
${ }^{30}$ SDG 16 Conference - Outcomes and key recommendations: https://sustainabledevelopment.un.org /content/documents/23814SDG_16_MAIN_SUMMARY_SDG_Conference_Rome_May2019.pdf ${ }^{31}$ https://tapnetwork2030.org/wp-content/uploads/2019/05/Rome-Civil-Society-Declaration-onSDG16-FINAL.pdf

${ }^{32}$ https://www.youth4peace.info/node/343
} 


\section{References}

Institute of Economics and Peace - Global Peace Index 2020: Measuring Peace in a Complex World. http://visionofhumanity.org/app/uploads/2020/06/GPI_2020_web.pdf

OECD - DAC Reccomendations on the Humanitarian, Peace, Development Nexus. https://legalinstruments.oecd.org/public/doc/643/643.en.pdf

OXFAM - The Humanitarian, Development, Peace Nexus. https://reliefweb.int/sites/reliefweb.int /files/resources/dp-humanitarian-development-peace-nexus-260619-en_0.pdf

OIM - Operationalizing the Humanitarian - Development - Peace Nexus: Lessons from Colombia, Mali, Nigeria, Somalia and Turkey. https://publications.iom.int/books/operationalizinghumanitarian-development-peace-nexus-lessons-colombia-mali-nigeria-somalia

OCHA - New way of Working. https://www.agendaforhumanity.org/sites/default/files /20170228\%20NWoW\%2013\%20high\%20res.pdf

Overseas Development Institute (ODI) - Grand Bargain annual independent report 2020 https://interagencystandingcommittee.org/system/files/2020-06/Grand\%20Bargain\%20Annual \%20Independent\%20Report\%202020_0.pdf

UN-World Bank - Pathways for Peace: Inclusive Approaches to Preventing Violent Conflict. https://openknowledge.worldbank.org/handle/10986/28337

Security Council mandated Progress Study on Youth, Peace and Security. https://www.youth4peace.info/ProgressStudy

Report of the Rome SDG 16 Conference (2019) - Outcome: Key messages and Recommendations. https://sustainabledevelopment.un.org/content/documents/23814SDG_16_MAIN_SUMMA RY_SDG_Conference_Rome_May2019.pdf

International Peace Institute- Sustaining Peace: What does it mean in Practice? https://www.ipinst.org/wp-content/uploads/2017/04/1704_Sustaining-Peace-final.pdf

Pathfinders - The Roadmap for Peaceful, Just and Inclusive Societies: A call to action to change our world. https://530cfd94-d934-468b-a1c7-c67a84734064.filesusr.com/ugd/6c192f _0349710665254122b0a00066c31fa8d2.pdf

UNICEF - Navigating the humanitarian-development nexus in forced displacement contexts. https://www.unicef.org/esa/media/4866/file

UN Evaluation Group - Humanitarian-Development Nexus: what do evaluations have to say? http://www.uneval.org/document/detail/2120

Steven, Locke, Ruttinger - Beyond 16: The SDGs and the opportunity to build a more peaceful world. https://static.wixstatic.com/ugd/6c192f_708dc5b85c4c4d2b9d1bceb791b72125.pdf 